\title{
STUDY OF HISTOMORPHOLOGICAL LESIONS OF FALLOPIAN TUBES
}

\author{
K. V. Sathish Arora1 ${ }^{1}$ K. Sreenivasulu2 ${ }^{2}$ M. Janaki³, Venkata Harish ${ }^{4}$, Vamshaj Raja ${ }^{5}$
}

\section{HOW TO CITE THIS ARTICLE:}

K. V. Sathish Arora, K. Sreenivasulu, M. Janaki, Venkata Harish, Vamshaj Raja. "Study of Histomorphological Lesions of Fallopian Tubes". Journal of Evolution of Medical and Dental Sciences 2015; Vol. 4, Issue 40, May 18; Page: 6938-6943, DOI: 10.14260/jemds/2015/1008

ABSTRACT: BACKGROUND: Fallopian tubes are the common surgical specimens in the pathology laboratory. Still there is lack of data to describe the frequency of various histopathological findings. To study the lesions encountered in the fallopian tube. AIMS AND OBJECTIVES: 1 . To study the lesions encountered in the fallopian tubes. 2. To study the various histopathological findings of fallopian tubes. MATERIAL AND METHODS: Six hundred and twenty fallopian tube specimens either received separately or as hysterectomy specimens were examined grossly and histopathologically. ${ }^{1}$ Data collected were analysed. The microscopic findings were analysed based on the clinical diagnosis. RESULTS: Majority (228) cases of tubal pathology with inflammatory lesions followed by ectopic pregnancies (18cases). Primary neoplastic lesions were rare finding. Serial sections of the fallopian tubes and sections from representative areas are essential for a histopathologist so that the diagnosis of these pathological entities is not missed. CONCLUSION: Though the fallopian tubes remain unremarkable in a majority of the surgical pathology specimens, they must be subjected for histopathological examination to evaluate the various pathological lesions.

KEYWORDS: Fallopian tube lesions, inflammatory lesions, neoplastic lesions.

INTRODUCTION: The fallopian tubes are complex structures; represent more than conduits from ovary to endometrial cavity. ${ }^{1}$ They are the seats of a variety of interactions that culminate in a normally implanted pregnancy. ${ }^{1}$ It is a common surgical specimen in pathology laboratory and may be examined either as salpingectomy or tubal ligation specimen or a part of hysterectomy and or oophorectomy specimen. ${ }^{2}$ There is lack of data to describe the frequency of various histological findings in a general surgical pathology. ${ }^{3}$ The aim and objective of the study was to describe the various histomorphological findings of fallopian tubes surgically removed as a part of hysterectomy as tubal ligation, unilateral salpingectomy and salpingoophorectomy.

MATERIAL AND METHODS: A two years prospective study was done from June 2012 - August 2014 at Shantiram Medical College and Hospital, Nandyal, Kurnool. During this period a study of 620 fallopian tubes were done. All the specimens of salpingectomy either done for TAH with BSO, unilateral salpingectomy or salpingoophorectomy were included in the study. The clinical data, gross and microscopic examination of the fallopian tubes were carried out by receiving the $\mathrm{H}$ and $\mathrm{E}$ stained sections. The para tubal cysts were excluded from the study.

RESULTS: Six hundred and twenty specimens consisting of various gynaecological lesions were studied. In the majority of cases the clinical diagnosis was Fibroid uterus (210) or dysfunctional uterine bleeding (DUB) 122 cases. 
ORIGINAL ARTICLE

\begin{tabular}{|c|c|c|c|}
\hline $\begin{array}{r}\text { Sl. } \\
\text { No. }\end{array}$ & Type of disease & No. of cases & Incidence \% \\
\hline 1 & DUB & 122 & 19.68 \\
\hline 2 & Fibroid & 210 & 33.87 \\
\hline 3 & Ectopic pregnancy & 18 & 12.90 \\
\hline 4. & Tubo ovarian mass & 66 & 10.65 \\
\hline 5. & Chronic cervicitis & 108 & 17.42 \\
\hline 6. & Prolapse of uterus & 10 & 1.67 \\
\hline 7. & Carcinoma of cervix & 18 & 2.90 \\
\hline 8. & Carcinoma of endometrium & 02 & 0.32 \\
\hline 9. & Infertility & 02 & 0.32 \\
\hline 10. & Tubectomy & 34 & 5.48 \\
\hline 11. & Others & 30 & 4.84 \\
\hline \multicolumn{3}{|c|}{ Table 1 } \\
\hline
\end{tabular}

The maximum number of cases belonged to the age group of 36-45 years, followed by 20-35 years of age group (Table.3). The youngest patient was 18 year old female where right salpingoophorectomy was done for ruptured ectopic pregnancy and the eldest was 65 years underwent hysterectomy for endometrial carcinoma. The prominent presenting symptom was vaginal bleeding followed by pain in abdomen. In half of the cases, there was pain in abdomen and lump in the abdomen. Out of 620 cases, 260 cases (41.93\%) showed tubal pathological lesions. The remaining cases of 360 cases (58.06\%) fallopian tubes were grossly, microscopically unremarkable.

\begin{tabular}{|c|c|c|c|}
\hline $\begin{array}{l}\text { Sl. } \\
\text { No. }\end{array}$ & Tubal lesions & No. cases & Incidence \% \\
\hline 1 & Normal & 360 & 58.06 \\
\hline 2 & Abnormal & 260 & 41.93 \\
\hline \multirow{6}{*}{3} & A) Acute salpingitis & 80 & 12.93 \\
\hline & B) Chronic salpingitis & 30 & 4.84 \\
\hline & C) salpingitis isthmica nodosa & 3 & 0.48 \\
\hline & D) Chronic non-specific salpingitis & 65 & 10.48 \\
\hline & E) Tuberculous & 6 & 0.96 \\
\hline & F) Others suture granuloma & 04 & 0.64 \\
\hline 4 & Hydrosalpinx & 40 & 6.45 \\
\hline 5 & Pyosalpinx & 04 & 0.64 \\
\hline 6 & Hemato salpinx & 04 & 0.64 \\
\hline 7 & Ectopic Pregnancy & 18 & 2.90 \\
\hline 8 & Endometriosis & 02 & 0.32 \\
\hline 9 & Torsion of the tube & 02 & 0.32 \\
\hline 10 & Benign & - & - \\
\hline \multirow{2}{*}{11} & Malignant Primary & 02 & 0.32 \\
\hline & Malignant Secondary & - & - \\
\hline
\end{tabular}




\section{ORIGINAL ARTICLE}

\begin{tabular}{|c|c|c|c|c|c|c|}
\hline $\begin{array}{l}\text { Sl. } \\
\text { No. }\end{array}$ & Type of disease & $\begin{array}{l}20-30 \\
\text { Years }\end{array}$ & $\begin{array}{l}30-40 \\
\text { years }\end{array}$ & $\begin{array}{l}40-50 \\
\text { years }\end{array}$ & $\begin{array}{l}50-60 \\
\text { years }\end{array}$ & $\begin{array}{l}60-70 \\
\text { years }\end{array}$ \\
\hline 1 & Acute salpingitis & 45 & 35 & - & - & - \\
\hline 2 & Chronic salpingitis & 08 & 22 & - & - & - \\
\hline 3 & salpingitis isthmica nodosa & - & 03 & - & - & - \\
\hline 4 & Chronic non-specific salpingitis & 10 & 35 & 20 & - & - \\
\hline 5 & Tuberculous & 4 & 2 & - & - & - \\
\hline 6 & Others suture granuloma & 1 & 3 & - & - & - \\
\hline 7 & Hydrosalpinx & 8 & 13 & 14 & 5 & - \\
\hline 8 & Pyosalpinx & 1 & 3 & - & - & - \\
\hline 9 & Hemato salpinx & 2 & 2 & - & - & - \\
\hline 10 & Ectopic Pregnency & 14 & 4 & - & - & - \\
\hline 11 & Endometriosis & - & 2 & - & - & - \\
\hline 12 & Torsion of the tube & - & 2 & - & - & - \\
\hline 13 & Adenocarcinoma of tube & - & - & - & 1 & - \\
\hline 14 & Transitional cell carcinoma & - & - & - & - & 1 \\
\hline
\end{tabular}

Salpingitis were the major group of inflammatory lesions, the incidence being $36.77 \%$ (228 cases). Majority cases of acute salpingitis were noted in the age group of 20-30 yrs. Most of the cases were misdiagnosed as acute appendicitis (on laparotomy purulent flakes are found on the tubes). In the remaining cases, acute salpingitis was observed as an incidental finding in hysterectomy specimens of various gynecological disorders. Bilateral salpingitis was found in most of the cases and showed congestion. 30 cases (4.84\%) were of chronic salpingitis which included 3 cases of salpingitis isthemic nodosa, show fibrous adhesions. Tuberculous salpingitis (Fig. 1) was suspected on gross examination and histopathological examination was confirmed in six cases. (0.96\%)

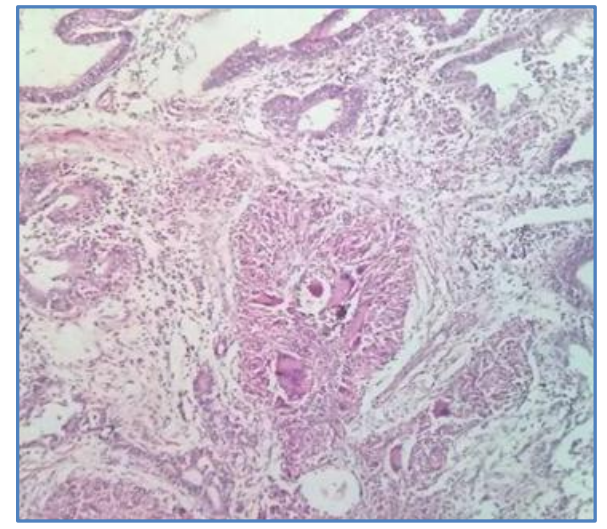

\section{Fig. 1: Tuberculous salpingitis (40x)}

Hydrosalpinx noted in 40 cases, pyosalpinx, endometriosis, hematosalpinx, torsion constituted a small percentage of cases. 18 cases of tubal ectopic pregnancies with the incidence $2.90 \%$ was noted. 
Ampulla was the commonest site of ectopic gestation with tubal rupture being common outcome in $60 \%$ of the cases. The primary neoplasm of the fallopian tubes were found only in 2 cases and observed in post-menopausal patients, presenting with non-specific symptoms like vague abdominal pain and watery vaginal discharge. The diagnosis was not made pre-operatively. Unilateral involvement was noted, tumor limited to serosa only. Histologically the tumor was primary adenocarcinoma.

DISCUSSION: Among 620 cases, tubal pathology was noted in 41.93\%, Bagwan et al 4 found 33.48\% of tubes with pathological lesions. The inflammatory tubal pathology constituted the major bulk of the 228 cases (36.77\%), whereas Bagwan et $\mathrm{al}^{4}$ reported $18.05 \%$. In the present study the incidence was more. Etiological sub typing of salpingitis was possible in 188 cases while remaining 40 cases showed hydrosalpinx which is a sequale of acute salpingitis. Similar findings are noted by others.1,5,6

The clinical presentation in these cases were variable, confirmative diagnosis was made in only $40 \%$ of cases, while in the remaining the diagnosis of salpingitis was made after histological examination.

Patton et $\mathrm{al}^{7}$ described the "silent salpingtis", where the pathological process is of overt salpingitis, but without any clinical symptoms. In the present study some cases of salpingitis might have remained silent and were diagnosed as incidental findining in histopathological examination. In the present study 6 cases $(0.96 \%)$ of tuberculuous salpingitis, adenomatous hyperplasia of the tubal lining was noted. Moore SW et al $^{8}$ stated that these findings in the tube suggest search for tuberculosis.

Infertility was observed in association with acute, chronic, tuberculous salpingitis, highlights the inflammatory tubal pathology in causing tubal block and hence infertility. Similar observations noted by Urman et al, ${ }^{9}$ Agarwal et $\mathrm{al}^{10}{ }^{10}$ Gon $\mathrm{S}$ et $\mathrm{al}^{3}$ found declining incidence of female genital tuberculosis. In the present study similar observations were noted.

In the present study 3 cases of salpingitis isthmica nodosa was seen. In one case, it was associated with ectopic pregnancy of the tube existing as a risk factor. Similar findings were noted by Majmudar et $\mathrm{al}^{11}$ and Bagwan et al. ${ }^{4}$ in the present study chronic non-specific salpingitis in 65 cases where as Gon $\mathrm{S}$ et $\mathrm{al}^{3}$ observed 56 cases, indicating mild increasing in the incidence. Two cases of endometriosis were observed in the present study, whereas Bagwan et $\mathrm{al}^{4}$ was noted on case with complaint of severe pelvic pain.

Bagwan et al, ${ }^{4}$ noted $11.79 \%$ (87 cases) of tubal ectopic pregnancies. Ampulla was the commonest site with rupture being the common complication. Similar findings observed by Job-spira et al. ${ }^{6}$ In the present study $2.9 \%$ (18 cases) were noted. Our study differed with Bagwan et al,4 correlated with histological findings of Job-spira et al. ${ }^{6}$

Cystic lesions of the tube though commonly seen did not have much clinical significance. The primary fallopian tube Adenocarcinoma accounts for $1 \%$ of all female genital tract malignancies. In the present study 2 cases $(0.03 \%)$ and Bagwan et al 2 cases $(0.15 \%)$ observed. Study correlated with others. Primary adenocarcinoma and transitional cell carcinoma of the fallopian tubes were found in the post-menopausal women, present with non-specific symptoms like abdominal pain and watery vaginal discharge similar observation noted by others.6,12,13 Majority of the patients with fallopian tube carcinoma presented with stage II disease at diagnosis but survival is low compared with other early stage gynaecological malignancies.12,14,15 
Longacre et al,14 attributed low incidence of primary malignancy in part admittedly due to orbitary definitional criteria as it is difficult to distinguish primary tubal carcinoma from primary ovarian or endometrial carcinoma in patients with high stage disease. It is essential for the pathologist to section the fallopian tubes serially and submit all of the tissue for microscopic examination so that the diagnosis of carcinoma is not missed.16

CONCLUSSION: Though the fallopian tubes remain unremarkable in majority of the surgical specimens, it must be subjected for histopathological examination to demonstrate the pathological lesions. It is also essential for the pathologist to section the fallopian tubes serially and submit all of the representative tissue for microscopic examination, so that the diagnosis of these pathological entities is not missed. In the present study the inflammatory lesions were the common entities.

\section{REFERENCES:}

1. Anderson MC. The fallopian tube. In: Symmers WSC ed. Systemic Pathology: Female Reproductive system. London: Churchill Livingstone.1991: 241-61.

2. Jennifer L. Hunt amy A Lynn. Histologic features of surgically removed fallopian tubes Archives of pathology and laboratory medicine 2002, 126.951-5.

3. Gon S Basu A, Manjundas B, Das TK, Sengupta M, Ghosh De et al. Spectrum of histopathological lesions in the fallopian tubes. J. Path. Nepal 2013; 3, 356-360.

4. Bagwan IN, Harke AB, Malpani MR, Deshmukh SD. Histopathological study lof spectrumofesions found in the fallopian tubes, J Obstet Gynecol Ind 2004; 54: 379-82.

5. Gompel C, Silverberg SG. Pathology in gynecology and obstetrics, $3^{\text {rd }}$ ed.Philadelphia:jb Lippincort company,1985, 278-305.

6. Job-Spira N, Fernandez H, Bouyer J et al. Ruptured tubal ectopic pregnancy: risk factors and reproductive outcome; results of population based study in france. Am J Obstet Gynecol 1999, 180: 938-44.

7. Patton DL, Moore DE, Spadoni LR et al. A comparison of the fallopian tubes response to overt and silent salpingitis. Obstet Gynecol 1975; 45: 385-90.

8. Moore SW, Enterline HT. Significance of proliferative epit8helial lesios of the uterine tube. Obstet Gynecol 1975; 45: 385-90.

9. Urman B, Gome IV, Mc Comb P et al. Mid tubal occusion: Etiology, management and outcome. Fertil Steril 1992; 57: 747-50.

10. Agarwal J Gupta JK. Female genital tuberculosis- a prospective clinic-pathologic study of 501 cases Indian J Pathol Microbiol 1993; 36: 389-97.

11. Majmudar B, Henderson PH, Semple E. Salpingitisisthemic nodosa; A high risk for tubal pregnancy. Obstet Gynecol 1983; 2: 73-50.

12. Schneider C, Wright E, Perucchini D et al. Primary carcimoma of the fallopian tube. A report of 19 cases with review of literature. Eur J Gynecol Oncol 2000; 21: 578-82.

13. Obermair A, Taylor $\mathrm{KH}$, Janda M, Nicklin M. The primary fallopian tube carcinoma the queenland experience. Ind J gynecol cancer 2001; 11: 69-72.

14. Longarce TV, Oliva E, Soslow RA. Association of directors of anatomic and surgical pathology recommendations for the reporting of fallopian tube neoplasms. Hum Pathol 2007; 38, 1160-3. 


\section{ORIGINAL ARTICLE}

15. Ajith kumar TV, Minimole AL, John MM. Primary fallopian tube carcinoma. Obstet gynecol Surv 2005; 60: 247-52.

16. Colgan PJ. Challenges in early diagnosis and staging of fallopian tube carcinoma associated with BRCA mutations. Int J Gyneco Pathol 2003; 22: 109-20.

\section{AUTHORS:}

1. K. V. Sathish Arora

2. K. Sreenivasulu

3. M. Janaki

4. Venkata Harish

5. Vamshaj Raja

\section{PARTICULARS OF CONTRIBUTORS:}

1. Associate Professor, Department of Pathology, Santiram Medical College, Nandyal, Kurnool.

2. Associate Professor, Department of Pathology, RIMS Ongole.

3. Professor \& HOD, Department of Pathology, SRMC, Nandyal, Kurnool.
4. Assistant Professor, Department of Pathology, SRMC, Nandyal, Kurnool.

5. $2^{\text {nd }}$ Year Post Graduate, Department of Pathology, SRMC, Nandyal, Kurnool.

\section{NAME ADDRESS EMAIL ID OF THE}

\section{CORRESPONDING AUTHOR:}

Dr. M. Janaki,

\# 40/241, Bangar Peta,

Kurnool-518004,

Andhra Pradesh.

E-mail: dr.mjanaki2009@gmail.com

Date of Submission: 29/04/2015.

Date of Peer Review: 30/04/2015.

Date of Acceptance: 08/05/2015.

Date of Publishing: 15/05/2015. 